HeALy, A. F. (1994). Letter detection: A window to unitization and other cognitive processes in reading text. Psychonomic Bulletin \& Review, 1, 333-344.

Healy, A. F., Conboy, G. L., \& Drewnowski, A. (1987). Characterizing the processing units of reading: Effects of intra- and interword spaces in a letter detection task. In B. K. Britton \& S. M. Glynn (Eds.), Executive control processes in reading (pp. 279-296). Hillsdale, NJ: Erlbaum.

Healy, A. F., \& DrewnowsKi, A. (1983). Investigating the boundaries of reading units: Letter detection in misspelled words. Journal of Experimental Psychology: Human Perception \& Performance, 9, 413-426.

Healy, A. F., Fendrich, D. W., \& Proctor, J. D. (1990). Acquisition and retention of a letter-detection skill. Journal of Experimental Psychology: Learning, Memory, \& Cognition, 16, 270-281.

Koriat, A., \& Greenberg, S. N. (1991). Syntactic control of letter detection: Evidence from English and Hebrew nonwords. Journal of Experimental Psychology: Learning, Memory, \& Cognition, 17, 1035-1050.

Koriat, A., \& Greenberg, S. N. (1993). Prominence of leading functors in function morpheme sequences as evidenced by letter detection. Journal of Experimental Psychology: Learning, Memory, \& Cognition, 19, 34-50.

Koriat, A., \& GreenberG, S. N. (1994). The extraction of phrase structure during reading: Evidence from letter detection errors. Psychonomic Bulletin \& Review, 1, 345-356.

Koriat, A., \& GreenberG, S. N. (1996). The enhancement effect in letter detection: Further evidence for the structural model of reading. Journal of Experimental Psychology: Learning, Memory, \& Cognition, 22, $1184-1195$.

Koriat, A., Greenberg, S. N., \& Goldshmid, Y. (1991). The missingletter effect in Hebrew: Word frequency or word function? Journal of Experimental Psychology: Learning, Memory, \& Cognition, 17, 66-80.

Moravcsik, J. E., \& Healy, A. F. (1995). Effect of meaning on letter detection. Journal of Experimental Psychology: Learning, Memory, \& Cognition, 21, 82-95.

Schneider, V. I., \& Healy, A. F. (1993). Detecting phonemes and letters in text: Interactions between different types and levels of processes. Memory \& Cognition, 21, 739-751.

Schneider, V. I., Healy, A. F., \& Gesi, A. T. (1991). The role of phonetic processes in letter detection: A reevaluation. Journal of Memory \& Language, 30, 294-318.

\section{NOTE}

1. According to Collins Robert (1987), there is no direct translation of this conjunction. English equivalents could include however or whereas.

(Manuscript received June 28, 1995; revision accepted for publication August 22, 1996.)

\title{
38th Annual Meeting of the Psychonomic Society Philadelphia, Pennsylvania November 20-23, 1997
}

The 38th Annual Meeting of the Psychonomic Society will be held in Philadelphia, Pennsylvania, at the Marriott Hotel. Registration will begin on Thursday evening, November 20. A poster session will be held on Thursday evening; spoken sessions will begin on the morning of Friday, November 21. Sessions will continue through noon on Sunday, November 23.

Programs and hotel reservation cards will be mailed to members and associates in September. Additional programs will be available at the meeting registration desk for $\$ 10.00$.

For further information, please contact the Secretary-Treasurer of the Society: Roger L. Mellgren, Department of Psychology, Box 19528, University of Texas, Arlington, TX 76019-0528 (phone: 817-272-2775; fax: 817-272-2364; e-mail: mellgren@uta.edu). 